\title{
Editorial
}

\section{Eberhard F. Mammen Award Announcements: Part I-Most Popular Articles}

\author{
Emmanuel J. Favaloro, PhD, FFSc (RCPA) ${ }^{1}$ \\ ${ }^{1}$ Department of Haematology, Institute of Clinical Pathology and \\ Medical Research (ICPMR), Westmead Hospital, Westmead, \\ New South Wales, Australia
}

Semin Thromb Hemost 2014;40:407-412.

Welcome to another Eberhard F. Mammen award announcement. As noted previously, ${ }^{1-3}$ Thieme, the publisher of Seminars in Thrombosis E Hemostasis, has created the Eberhard F. Mammen Excellence in Thrombosis and Hemostasis Awards in the honor of Dr. Eberhard F. Mammen (-Fig. 1), and in recognition of his contribution to this field and to the journal that he both founded and steered for over three decades. These awards began in 2009 under two categories:

- Most Popular Article Awards: Awarded to the authors of the most popular articles published in Seminars in Thrombosis $\mathcal{E}$ Hemostasis. The awards are determined by the Editor in Chief on the basis of user statistics from Thieme e-Journals from the preceding 2 years. The awards comprise two major cash prizes of US $\$ 1,000$ plus “open access" status for these articles thereafter.

- Young Investigator Awards: Best presentation or meeting abstract by a young investigator-as presented or delivered to an international or large regional meeting on a topic related to the fields of thrombosis and hemostasis and whose subject matter is determined to be in the spirit of Dr. Mammen. Up to six cash prizes of US\$1,000 are awarded in any year. Awardees are expected to prepare a review or an article related to the topic of their presentation for publication in Seminars in Thrombosis E Hemostasis.

Further details of the awards and the award winners are posted online (<http://www.thieme.com/sth $>$ ), and previous award winner announcements are also available in print. ${ }^{4-9}$

It is, therefore, with great pleasure that we would like to announce the latest winners of the 2014 Eberhard F. Mammen awards for the most popular articles from Seminars in Thrombosis \&'Hemostasis for the period 2012 to 2013 inclusive.

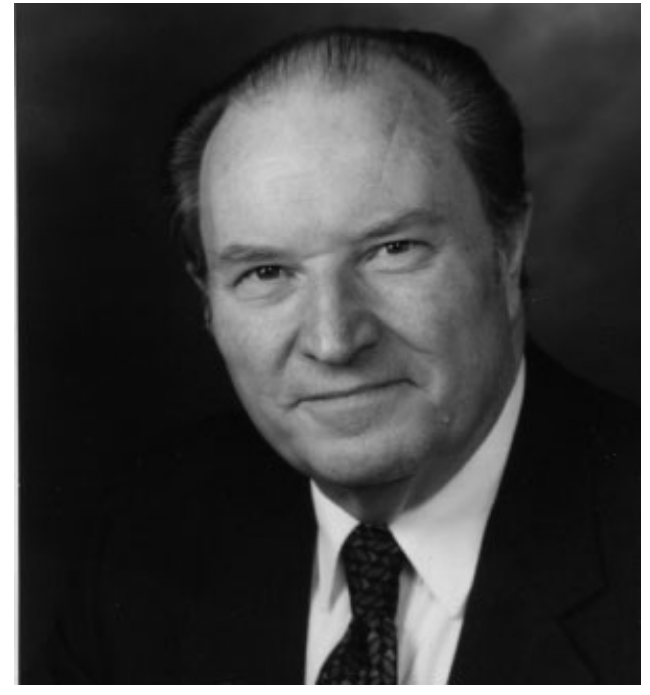

Fig. 1 Eberhard F. Mammen (1930-2008).

We will be announcing the young investigator awards related to meetings held in the recent past on a later date.

\section{4 "Most Popular” Article Awards}

As mentioned, the "most popular" awards are given to the authors of the most popular articles published in Seminars in Thrombosis $\mathcal{E}$ Hemostasis as determined on the basis of user statistics from the publisher of this journal and covering the preceding 2-year period. Thus, the 2014 "most popular" awards are granted to the most popular articles from 2012 to 2013. However, this year saw the continuing trend to the ongoing presence of many of the previous "most popular" awardees on the STH top 100 listing of most popular articles.
Address for correspondence Emmanuel J. Favaloro, PhD, FFSc (RCPA), Department of Haematology, Institute of Clinical Pathology and Medical Research (ICPMR), Westmead Hospital, Westmead, New South Wales 2145, Australia (e-mail: emmanuel. favaloro@health.nsw.gov.au).
Issue Theme An Update on the Thrombotic Microangiopathies Hemolytic Uremic Syndrome (HUS) and Thrombotic Thrombocytopenic Purpura (TTP); Guest Editors, Magdalena Riedl, MD, Dorothea Orth-Höller, MD, and Reinhard Würzner, MD, PhD.
Copyright $\odot 2014$ by Thieme Medical Publishers, Inc., 333 Seventh Avenue, New York, NY 10001, USA. Tel: +1(212) 584-4662.
DOI http://dx.doi.org/ 10.1055/s-0034-1376151. ISSN 0094-6176. 
Table 1 Top 50 downloaded non-open-access articles from Seminars in Thrombosis \& Hemostasis (2012 and 2013 inclusive)

\section{Rank, articles}

1. Chapman K, Seldon M, Richards R. Thrombotic microangiopathies, thrombotic thrombocytopenic purpura, and ADAMTS-13. Semin Thromb Hemost 2012;38(1):47-54

2. Kenet G, Aronis S, Berkun Y, et al. Impact of persistent antiphospholipid antibodies on risk of incident symptomatic thromboembolism in children: a systematic review and meta-analysis. Semin Thromb Hemost 2011;37(7):802-809

3. Aatonen M, Grönholm M, Siljander PR. Platelet-derived microvesicles: multitalented participants in intercellular communication. Semin Thromb Hemost 2012;38(1):102-113

4. Kulkarni R, Soucie JM. Pediatric hemophilia: a review. Semin Thromb Hemost 2011;37(7):737-744

5. Stasi R. Immune thrombocytopenia: pathophysiologic and clinical update. Semin Thromb Hemost 2012;38(5):454-462

6. Lyle CA, Bernard TJ, Goldenberg NA. Childhood arterial ischemic stroke: a review of etiologies, antithrombotic treatments, prognostic factors, and priorities for future research. Semin Thromb Hemost 2011;37(7):786-793

7. Schulman S, Majeed A. The oral thrombin inhibitor dabigatran: strengths and weaknesses. Semin Thromb Hemost 2012;38 (1):7-15

8. Kadir RA, McLintock C. Thrombocytopenia and disorders of platelet function in pregnancy. Semin Thromb Hemost 2011;37 (6):640-652

9. Tan CW, Ward CM, Morel-Kopp MC. Evaluating heparin-induced thrombocytopenia: the old and the new. Semin Thromb Hemost 2012;38(2):135-143

10. Breakey VR, Blanchette VS. Childhood immune thrombocytopenia: a changing therapeutic landscape. Semin Thromb Hemost 2011;37(7):745-755

11. Lacroix R, Robert S, Poncelet P, Dignat-George F. Overcoming limitations of microparticle measurement by flow cytometry. Semin Thromb Hemost 2010;36(8):807-818

12. Jayandharan GR, Srivastava A, Srivastava A. Role of molecular genetics in hemophilia: from diagnosis to therapy. Semin Thromb Hemost 2012;38(1):64-78

13. Coppola A, Favaloro EJ, Tufano A, Di Minno MN, Cerbone AM, Franchini M. Acquired inhibitors of coagulation factors: part Iacquired hemophilia A. Semin Thromb Hemost 2012;38(5):433-446

14. Bates SM. D-dimer assays in diagnosis and management of thrombotic and bleeding disorders. Semin Thromb Hemost 2012;38(7):673-682

15. Pels SG. Current therapies in primary immune thrombocytopenia. Semin Thromb Hemost 2011;37(6):621-630

16. Prechel M, Walenga JM. Heparin-induced thrombocytopenia: an update. Semin Thromb Hemost 2012;38(5):483-496

17. Szántó T, Joutsi-Korhonen L, Deckmyn H, Lassila R. New insights into von Willebrand disease and platelet function. Semin Thromb Hemost 2012;38(1):55-63

18. Willis R, Harris EN, Pierangeli SS. Pathogenesis of the antiphospholipid syndrome. Semin Thromb Hemost 2012;38(4):305321

19. Harenberg J, Giese C, Marx S, Krämer R. Determination of dabigatran in human plasma samples. Semin Thromb Hemost 2012;38(1):16-22

20. Harenberg J, Erdle S, Marx S, Krämer R. Determination of rivaroxaban in human plasma samples. Semin Thromb Hemost 2012;38(2):178-184

21. Favaloro EJ, Wong RC. The antiphospholipid syndrome: diagnosis, pathogenesis, laboratory testing, and management. Semin Thromb Hemost 2012;38(4):299-304

22. Coppola A, Tagliaferri A, Di Capua M, Franchini M. Prophylaxis in children with hemophilia: evidence-based achievements, old and new challenges. Semin Thromb Hemost 2012;38(1):79-94

23. Linden MD, Tran H, Woods R, Tonkin A. High platelet reactivity and antiplatelet therapy resistance. Semin Thromb Hemost 2012;38(2):200-212

24. Coppola A, Tufano A, Di Capua M, Franchini M. Bleeding and thrombosis in multiple myeloma and related plasma cell disorders. Semin Thromb Hemost 2011;37(8):929-945

25. Montagnana M, Favaloro EJ, Lippi G. Coffee intake and cardiovascular disease: virtue does not take center stage. Semin Thromb Hemost 2012;38(2):164-177

26. Tsai HM. Autoimmune thrombotic microangiopathy: advances in pathogenesis, diagnosis, and management. Semin Thromb Hemost 2012;38(5):469-482

27. Scharf RE. Drugs that affect platelet function. Semin Thromb Hemost 2012;38(8):865-883

28. Galli M. Interpretation and recommended testing for antiphospholipid antibodies. Semin Thromb Hemost 2012;38(4):348352

29. Zoellner H. Dental infection and vascular disease. Semin Thromb Hemost 2011;37(3):181-192

30. Lippi G, Favaloro EJ, Cervellin G. Prevention of venous thromboembolism: focus on mechanical prophylaxis. Semin Thromb Hemost 2011;37(3):237-251

31. Franchini M, Lippi G, Favaloro EJ. Acquired inhibitors of coagulation factors: part II. Semin Thromb Hemost 2012;38(5):447453

32. Rojas-Hernandez CM, Garcia DA. The novel oral anticoagulants. Semin Thromb Hemost 2013;39(2):117-126

33. Adams M. Tissue factor pathway inhibitor: new insights into an old inhibitor. Semin Thromb Hemost 2012;38(2):129-134

34. Les I, Ruiz-Irastorza G, Khamashta MA. Intensity and duration of anticoagulation therapy in antiphospholipid syndrome. Semin Thromb Hemost 2012;38(4):339-347

35. Köse O, Zimmerhackl LB, Jungraithmayr T, Mache C, Nürnberger J. New treatment options for atypical hemolytic uremic syndrome with the complement inhibitor eculizumab. Semin Thromb Hemost 2010;36(6):669-672 
Table 1 (Continued)

\section{Rank, articles}

36. Cervera R, Espinosa G. Update on the catastrophic antiphospholipid syndrome and the "CAPS Registry." Semin Thromb Hemost 2012;38(4):333-338

37. De Franceschi L, Cappellini MD, Olivieri O. Thrombosis and sickle cell disease. Semin Thromb Hemost 2011;37(3):226-236

38. Thom KE, Hanslik A, Male C. Anticoagulation in children undergoing cardiac surgery. Semin Thromb Hemost 2011;37(7):826-833

39. Bitzan M, Schaefer F, Reymond D. Treatment of typical (enteropathic) hemolytic uremic syndrome. Semin Thromb Hemost 2010;36(6):594-610

40. Flaumenhaft R, Mairuhu AT, Italiano JE. Platelet- and megakaryocyte-derived microparticles. Semin Thromb Hemost 2010;36 (8):881-887

41. Ranucci M, Baryshnikova E, Colella D. Monitoring prohemostatic treatment in bleeding patients. Semin Thromb Hemost 2012;38(3):282-291

42. Favaloro EJ. Clinical utility of the PFA-100. Semin Thromb Hemost 2008;34(8):709-733

43. Cuker A. Current and emerging therapeutics for heparin-induced thrombocytopenia. Semin Thromb Hemost 2012;38(1): 31-37

44. Toriello HV. Thrombocytopenia-absent radius syndrome. Semin Thromb Hemost 2011;37(6):707-712

45. Schroeder V, Kohler HP. Factor XIII deficiency: an update. Semin Thromb Hemost 2013;39(6):632-641

46. Kuperman AA, Kenet G, Papadakis E, Brenner B. Intraventricular hemorrhage in preterm infants: coagulation perspectives. Semin Thromb Hemost 2011;37(7):730-736

47. Heleen van Ommen C, Middeldorp S. Thrombophilia in childhood: to test or not to test. Semin Thromb Hemost 2011;37 (7):794-801

48. Darvish-Kazem S, Douketis JD. Perioperative management of patients having noncardiac surgery who are receiving anticoagulant or antiplatelet therapy: an evidence-based but practical approach. Semin Thromb Hemost 2012;38(7):652-660

49. Franchini M, Vescovi PP, Garofano M, Veneri D. Helicobacter pylori-associated idiopathic thrombocytopenic purpura: a narrative review. Semin Thromb Hemost 2012;38(5):463-468

50. Hellgren M. Hemostasis during normal pregnancy and puerperium. Semin Thromb Hemost 2003;29(2):125-130

Given that these articles are granted "open-access" status as part of the award, this ongoing presence on the most downloaded article listing may be in part due to their free availability in addition to their popularity per se. Also appearing on this 2012-2013 list was another "open-access" article. Since the open-access model of publishing makes articles much more freely available than non-open-access ones, this may generate an inequitable advantage for these in terms of download statistics. Accordingly, the publisher of Seminars in Thrombosis $\mathcal{E}$ Hemostasis has agreed to establish a separate category of the award for "open-access" articles. Accordingly, for this year and hereafter, the most popular articles will be listed in two separate tables. - Table 1 lists the top 50 most downloaded non-open-access articles from Seminars in Thrombosis $\mathcal{E}$ Hemostasis (2012 and 2013 inclusive). ${ }^{10-59}$-Table 2 lists the top most downloaded open-access articles from Seminars in Thrombosis $\mathcal{E}$ Hemostasis (2012 and 2013 inclusive) that appeared in the top 100 download list, including previous winners of this award. ${ }^{60-66}$ As previously highlighted in these editorials, ${ }^{9}$ previous winners of the award are not eligible for another award for the same article; hence, most of the articles listed in -Table 2 do not qualify for an award in 2014. The notable exception here is the top-listed article, ${ }^{60}$ which was published in 2012, and which has not previously been granted an award, and, hence, certainly qualifies for the 2014 award. The two top-listed articles ${ }^{10,11}$ in - Table 1 are also winners of the 2014 Eberhard F. Mammen award for most popular article ("general category"). Accordingly, the 2014 Eberhard F. Mammen Award winners for most popular article (2012-2013 inclusive) are as follows:

Table 2 Top downloaded open access articles from Seminars in Thrombosis \& Hemostasis (2012 and 2013 inclusive)

\section{Rank, articles}

1. Salmela B, Joutsi-Korhonen L, Armstrong E, Lassila R. Active online assessment of patients using new oral anticoagulants: bleeding risk, compliance, and coagulation analysis. Semin Thromb Hemost 2012;38(1):23-30

2. Lippi G, Franchini M, Favaloro EJ, Targher G. Moderate red wine consumption and cardiovascular disease risk: beyond the "French paradox." Semin Thromb Hemost 2010;36(1):59-70

3. Rak J. Microparticles in cancer. Semin Thromb Hemost 2010;36(8):888-906

4. Jurk K, Kehrel BE. Platelets: physiology and biochemistry. Semin Thromb Hemost 2005;31(4):381-392

5. Tufano A, Guida A, Di Minno MN, Prisco D, Cerbone AM, Di Minno G. Prevention of venous thromboembolism in medical patients with thrombocytopenia or with platelet dysfunction: a review of the literature. Semin Thromb Hemost 2011;37 (3):267-274

6. Mariani G, Bernardi F. Factor VII deficiency. Semin Thromb Hemost 2009;35(4):400-406

7. Fava C, Montagnana M, Favaloro EJ, Guidi GC, Lippi G. Obstructive sleep apnea syndrome and cardiovascular diseases. Semin Thromb Hemost 2011;37(3):280-297 


\section{General Category}

1. Chapman K, Seldon M, Richards R. Thrombotic microangiopathies, thrombotic thrombocytopenic purpura, and ADAMTS-13. Semin Thromb Hemost 2012;38(1): 47-54.

2. Kenet G, Aronis S, Berkun Y, et al. Impact of persistent antiphospholipid antibodies on risk of incident symptomatic thromboembolism in children: a systematic review and meta-analysis. Semin Thromb Hemost 2011;37 (7):802-809.

\section{Open-Access Category}

1. Salmela B, Joutsi-Korhonen L, Armstrong E, Lassila R. Active online assessment of patients using new oral anticoagulants: bleeding risk, compliance, and coagulation analysis. Semin Thromb Hemost. 2012 Feb;38(1):23-30.

All authors of these award-winning articles were thrilled to hear that their articles had won an Eberhard F. Mammen Most Popular Award and provided the following additional responses.

From Kent Chapman (-Fig. 2): "As a scientist who performs ADAMTS-13 [a disintegrin and metalloproteinase with a thrombospondin type 1 motif, member 13] assays in the laboratory, I came to write this paper not only out of personal interest in the subject matter, but also as a part of the Master's degree I was enrolled in at the time. I also felt that the literature at the time regarding TTP [Thrombotic Thrombocytopenic Purpura] was lacking a comprehensive review of TMA [Thrombotic Microangiopathies], TTP, and ADAMTS-13 and it was my aim to try and collate all this information in one paper to help others with the understanding of a very complex and often misunderstood disease. I am delighted to receive this award and even more excited to realise that the paper has been as popular as it is."

Drs. Gili Kenet and Ulrike Nowak-Göttl (-Fig. 3), both pediatric hematologists with an interest in childhood hemostasis, provided the following commentary: "Because throm-

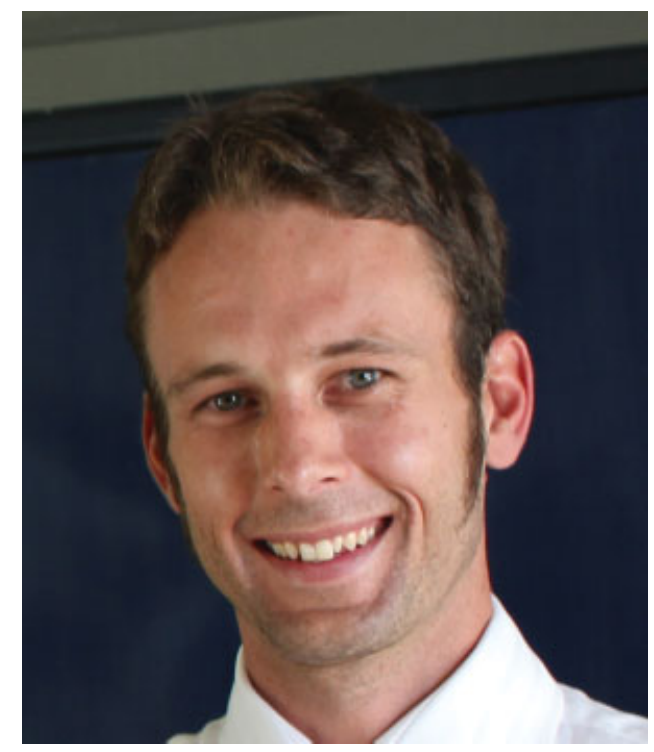

Fig. 2 Kent Chapman.

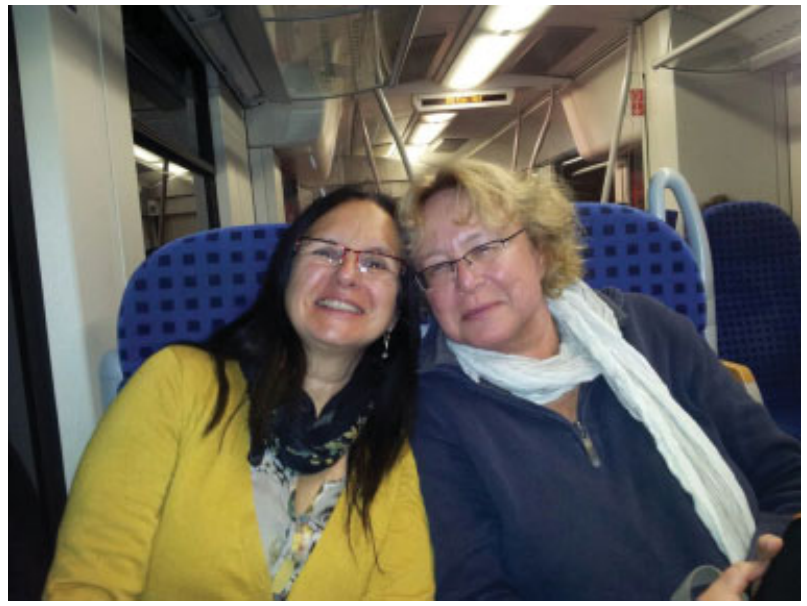

Fig. 3 Drs. Gili Kenet (left) and Ulrike Nowak-Göttl (right). The picture was taken in October 2013 in Kiel during the Congress of the Biannual Meeting of the Pediatric Society of Haematology and Immunology chaired by Prof. Nowak-Göttl.

boses and stroke in pediatric patients are rare diseases, conducting scientific studies within a single hospital or even within a single country is difficult. Aiming to gather scientific data and create recommendations that can be applied to a broad spectrum of children over the world we gathered together a large group of collaborators. We have previously chaired the pediatric/perinatal hemostasis scientific standardisation committee (SCC) of the International Society on Thrombosis and Haemostasis (ISTH), promoting international research collaboration and cooperative multicenter studies. The Eberhard Mammen awarded 'systematic review and meta-analysis on observational studies in children with antiphospholipid antibodies' is one example published by this international cooperative group and was first presented during the ISTH SSC 2010 meeting in Cairo, Egypt."

At the present time Prof. Kenet is director of the Thrombosis Unit and National Hemophilia Center in Tel Hashomer affiliated with the Sackler Medical School, Tel Aviv University in Israel, and Prof. Nowak-Göttl is head of the Thrombosis and Hemophilia Treatment Centre, Institute of Clinical Chemistry, at the University Hospital Schleswig-Holstein, Kiel \& Lubbock, Germany.

From Birgitta Salmela and Riitta Lassila (-Fig. 4): "The 2014 Eberhard F. Mammen 'Most Popular' articles award both surprised and delighted our team. At the time we wrote the article, only few practical insights into the topic were available. Therefore, we felt it important to share our clinical experience in view of the available studies. The variable and extensive exclusion criteria used in the clinical trial studies were not easy to find in the literature, methods to measure the anticoagulant effects when necessary were only available as research tools, and the absence of any specific antidotes raised serious concerns. As we encountered patients in need of urgent surgery or with new thrombosis while on new direct oral anticoagulant treatment, we felt it imperative to learn more about the field and to share our experience. Winning this award encourages us to continue to 


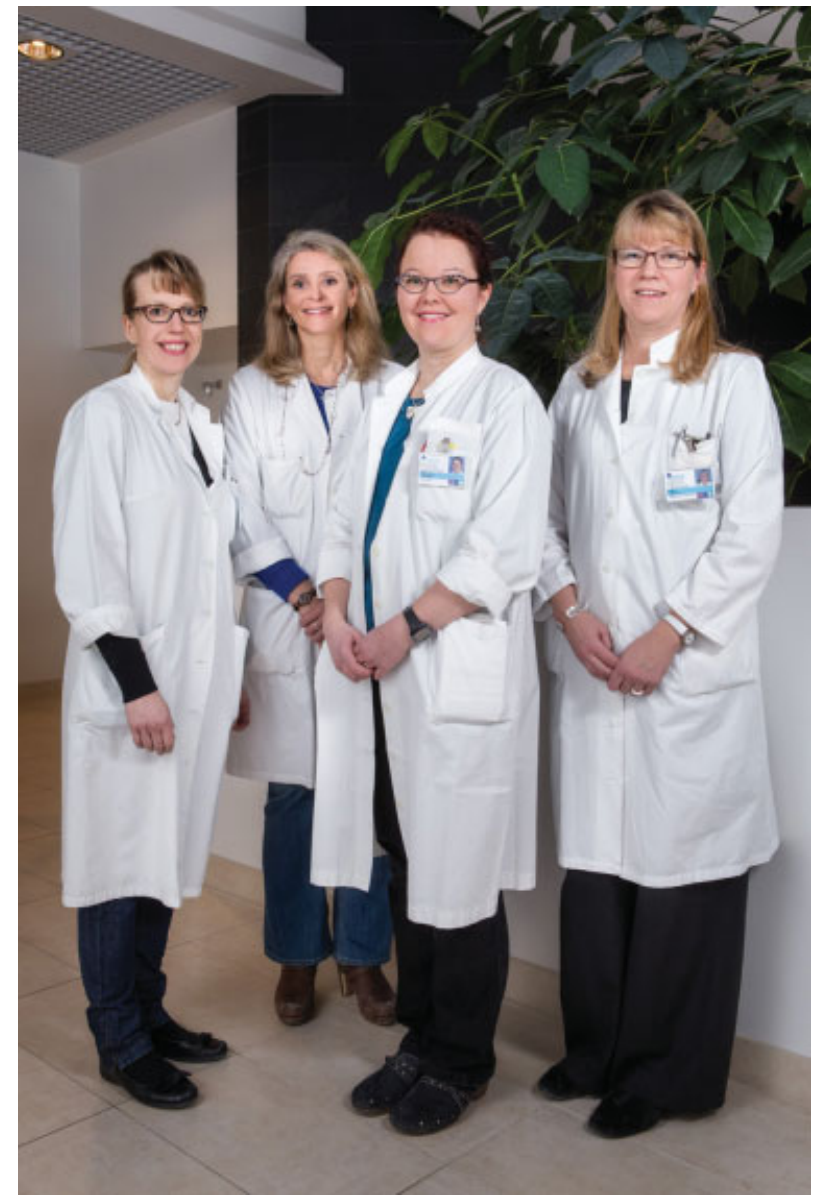

Fig. 4 From left to right: Drs. Lotta Joutsi-Korhonen, Elina Armstrong, Birgitta Salmela, and Riitta Lassila. Photo taken at Helsinki University Central Hospital.

be active in improving patient care, collaborate with our colleagues and to follow the field of new and developing anticoagulants. We are honored to be acknowledged in this way and look forward to reading the excellent articles appearing in Seminars in Thrombosis \& Hemostasis in the future."

It is also interesting (as always) to reflect on some of the other most popular articles, which relate to a variety of topics within the field of thrombosis and hemostasis. Of some continued interest, and analogous to previous years, is that (1) some articles from previous most popular award listings have appeared yet again (-Table 2 ), and this highlights their perpetuating interest to our readership, and (2) that many are from previous young investigator award winners (-Table 1). ${ }^{12,21,24,26,52}$ Indeed, what I find personally gratifying is that every young investigator award winner from 2010 (as announced in 2011) ${ }^{7}$ is listed in either - Table 1 or - Table $\mathbf{2}^{12,21,26,52,60}$ and also that every one of these articles also appeared within last year's top 100 listing. Also interesting is that a few articles on the top 50 listing ( - Table 1), included as authors, individuals who were later to be awarded a young investigator award, ${ }^{10,15,20,49}$ including one of the winners of the current "most popular" article award. ${ }^{10}$ These findings would appear to more than validate the young investigator award process, and I look forward to seeing their careers continue to develop.

I would like, as always, to thank not only all the authors listed in -Tables 1 and $\mathbf{2}$ but also the contributing authors who did not manage to make these listings, as well as all the guest editors of issues recently published in Seminars in Thrombosis \& Hemostasis. I look forward to seeing next year's listing!

\section{References}

1 Favaloro EJ. Editorial. Welcome to a special issue of Seminars in Thrombosis and Hemostasis-the closing issue for 2008. Semin Thromb Hemost 2008;34:693-696

2 Favaloro EJ. A tribute to Eberhard F. Mammen, M.D. (1930-2008). Semin Thromb Hemost 2008;34(8):703-707

3 Favaloro EJ. Editorial. Welcome to the first issue of Seminars in Thrombosis and Hemostasis for 2009. Semin Thromb Hemost 2009;35:1-2

4 Favaloro EJ. Editorial. Winners of the inaugural Eberhard F. Mammen Award for most popular article. Semin Thromb Hemost 2009; 35:587-590

5 Favaloro EJ. Editorial. 2009 Eberhard F. Mammen Young Investigator Award winners. Semin Thromb Hemost 2010;36: 469-470

6 Favaloro EJ. Winners of the 2010 Eberhard F. Mammen award for most popular article during 2008-2009. Semin Thromb Hemost 2010;36(7):685-692

7 Favaloro EJ. 2011 Eberhard F. Mammen award announcements. Semin Thromb Hemost 2011;37(5):431-439

8 Favaloro EJ. 2012 Eberhard F. Mammen award announcements. Semin Thromb Hemost 2012;38:425-432

9 Favaloro EJ. Eberhard F. Mammen award announcements. Semin Thromb Hemost 2013;39:567-574

10 Chapman K, Seldon M, Richards R. Thrombotic microangiopathies, thrombotic thrombocytopenic purpura, and ADAMTS-13. Semin Thromb Hemost 2012;38(1):47-54

11 Kenet G, Aronis S, Berkun Y, et al. Impact of persistent antiphospholipid antibodies on risk of incident symptomatic thromboembolism in children: a systematic review and meta-analysis. Semin Thromb Hemost 2011;37(7):802-809

12 Aatonen M, Grönholm M, Siljander PR. Platelet-derived microvesicles: multitalented participants in intercellular communication. Semin Thromb Hemost 2012;38(1):102-113

13 Kulkarni R, Soucie JM. Pediatric hemophilia: a review. Semin Thromb Hemost 2011;37(7):737-744

14 Stasi R. Immune thrombocytopenia: pathophysiologic and clinical update. Semin Thromb Hemost 2012;38(5):454-462

15 Lyle CA, Bernard TJ, Goldenberg NA. Childhood arterial ischemic stroke: a review of etiologies, antithrombotic treatments, prognostic factors, and priorities for future research. Semin Thromb Hemost 2011;37(7):786-793

16 Schulman S, Majeed A. The oral thrombin inhibitor dabigatran: strengths and weaknesses. Semin Thromb Hemost 2012;38(1): 7-15

17 Kadir RA, McLintock C. Thrombocytopenia and disorders of platelet function in pregnancy. Semin Thromb Hemost 2011;37(6): 640-652

18 Tan CW, Ward CM, Morel-Kopp MC. Evaluating heparin-induced thrombocytopenia: the old and the new. Semin Thromb Hemost 2012;38(2):135-143

19 Breakey VR, Blanchette VS. Childhood immune thrombocytopenia: a changing therapeutic landscape. Semin Thromb Hemost 2011;37(7):745-755 
20 Lacroix R, Robert S, Poncelet P, Dignat-George F. Overcoming limitations of microparticle measurement by flow cytometry. Semin Thromb Hemost 2010;36(8):807-818

21 Jayandharan GR, Srivastava A, Srivastava A. Role of molecular genetics in hemophilia: from diagnosis to therapy. Semin Thromb Hemost 2012;38(1):64-78

22 Coppola A, Favaloro EJ, Tufano A, Di Minno MN, Cerbone AM, Franchini M. Acquired inhibitors of coagulation factors: Part Iacquired hemophilia A. Semin Thromb Hemost 2012;38(5):433-446

23 Bates SM. D-dimer assays in diagnosis and management of thrombotic and bleeding disorders. Semin Thromb Hemost 2012;38(7): 673-682

24 Pels SG. Current therapies in primary immune thrombocytopenia. Semin Thromb Hemost 2011;37(6):621-630

25 Prechel M, Walenga JM. Heparin-induced thrombocytopenia: an update. Semin Thromb Hemost 2012;38(5):483-496

26 Szántó T, Joutsi-Korhonen L, Deckmyn H, Lassila R. New insights into von Willebrand disease and platelet function. Semin Thromb Hemost 2012;38(1):55-63

27 Willis R, Harris EN, Pierangeli SS. Pathogenesis of the antiphospholipid syndrome. Semin Thromb Hemost 2012;38(4):305-321

28 Harenberg J, Giese C, Marx S, Krämer R. Determination of dabigatran in human plasma samples. Semin Thromb Hemost 2012; 38(1):16-22

29 Harenberg J, Erdle S, Marx S, Krämer R. Determination of rivaroxaban in human plasma samples. Semin Thromb Hemost 2012; 38(2):178-184

30 Favaloro EJ, Wong RC. The antiphospholipid syndrome: diagnosis, pathogenesis, laboratory testing, and management. Semin Thromb Hemost 2012;38(4):299-304

31 Coppola A, Tagliaferri A, Di Capua M, Franchini M. Prophylaxis in children with hemophilia: evidence-based achievements, old and new challenges. Semin Thromb Hemost 2012;38(1):79-94

32 Linden MD, Tran H, Woods R, Tonkin A. High platelet reactivity and antiplatelet therapy resistance. Semin Thromb Hemost 2012; 38(2):200-212

33 Coppola A, Tufano A, Di Capua M, Franchini M. Bleeding and thrombosis in multiple myeloma and related plasma cell disorders. Semin Thromb Hemost 2011;37(8):929-945

34 Montagnana M, Favaloro EJ, Lippi G. Coffee intake and cardiovascular disease: virtue does not take center stage. Semin Thromb Hemost 2012;38(2):164-177

35 Tsai HM. Autoimmune thrombotic microangiopathy: advances in pathogenesis, diagnosis, and management. Semin Thromb Hemost 2012;38(5):469-482

36 Scharf RE. Drugs that affect platelet function. Semin Thromb Hemost 2012;38(8):865-883

37 Galli M. Interpretation and recommended testing for antiphospholipid antibodies. Semin Thromb Hemost 2012;38(4):348-352

38 Zoellner H. Dental infection and vascular disease. Semin Thromb Hemost 2011;37(3):181-192

39 Lippi G, Favaloro EJ, Cervellin G. Prevention of venous thromboembolism: focus on mechanical prophylaxis. Semin Thromb Hemost 2011;37(3):237-251

40 Franchini M, Lippi G, Favaloro EJ. Acquired inhibitors of coagulation factors: part II. Semin Thromb Hemost 2012;38(5):447-453

41 Rojas-Hernandez CM, Garcia DA. The novel oral anticoagulants. Semin Thromb Hemost 2013;39(2):117-126

42 Adams M. Tissue factor pathway inhibitor: new insights into an old inhibitor. Semin Thromb Hemost 2012;38(2):129-134

43 Les I, Ruiz-Irastorza G, Khamashta MA. Intensity and duration of anticoagulation therapy in antiphospholipid syndrome. Semin Thromb Hemost 2012;38(4):339-347
44 Köse O, Zimmerhackl LB, Jungraithmayr T, Mache C, Nürnberger J. New treatment options for atypical hemolytic uremic syndrome with the complement inhibitor eculizumab. Semin Thromb Hemost 2010;36(6):669-672

45 Cervera R, Espinosa G. Update on the catastrophic antiphospholipid syndrome and the "CAPS Registry". Semin Thromb Hemost 2012;38(4):333-338

46 De Franceschi L, Cappellini MD, Olivieri O. Thrombosis and sickle cell disease. Semin Thromb Hemost 2011;37(3):226-236

47 Thom KE, Hanslik A, Male C. Anticoagulation in children undergoing cardiac surgery. Semin Thromb Hemost 2011;37(7):826-833

48 Bitzan M, Schaefer F, Reymond D. Treatment of typical (enteropathic) hemolytic uremic syndrome. Semin Thromb Hemost 2010;36(6):594-610

49 Flaumenhaft R, Mairuhu AT, Italiano JE. Platelet- and megakaryocyte-derived microparticles. Semin Thromb Hemost 2010;36(8): 881-887

50 Ranucci M, Baryshnikova E, Colella D. Monitoring prohemostatic treatment in bleeding patients. Semin Thromb Hemost 2012; 38(3):282-291

51 Favaloro EJ. Clinical utility of the PFA-100. Semin Thromb Hemost 2008;34(8):709-733

52 Cuker A. Current and emerging therapeutics for heparin-induced thrombocytopenia. Semin Thromb Hemost 2012;38(1):31-37

53 Toriello HV. Thrombocytopenia-absent radius syndrome. Semin Thromb Hemost 2011;37(6):707-712

54 Schroeder V, Kohler HP. Factor XIII deficiency: an update. Semin Thromb Hemost 2013;39(6):632-641

55 Kuperman AA, Kenet G, Papadakis E, Brenner B. Intraventricular hemorrhage in preterm infants: coagulation perspectives. Semin Thromb Hemost 2011;37(7):730-736

56 Heleen van Ommen C, Middeldorp S. Thrombophilia in childhood: to test or not to test. Semin Thromb Hemost 2011;37(7): 794-801

57 Darvish-Kazem S, Douketis JD. Perioperative management of patients having noncardiac surgery who are receiving anticoagulant or antiplatelet therapy: an evidence-based but practical approach. Semin Thromb Hemost 2012;38(7):652-660

58 Franchini M, Vescovi PP, Garofano M, Veneri D. Helicobacter pyloriassociated idiopathic thrombocytopenic purpura: a narrative review. Semin Thromb Hemost 2012;38(5):463-468

59 Hellgren M. Hemostasis during normal pregnancy and puerperium. Semin Thromb Hemost 2003;29(2):125-130

60 Salmela B, Joutsi-Korhonen L, Armstrong E, Lassila R. Active online assessment of patients using new oral anticoagulants: bleeding risk, compliance, and coagulation analysis. Semin Thromb Hemost 2012;38(1):23-30

61 Lippi G, Franchini M, Favaloro EJ, Targher G. Moderate red wine consumption and cardiovascular disease risk: beyond the "French paradox". Semin Thromb Hemost 2010;36(1):59-70

62 Rak J. Microparticles in cancer. Semin Thromb Hemost 2010;36(8): 888-906

63 Jurk K, Kehrel BE. Platelets: physiology and biochemistry. Semin Thromb Hemost 2005;31(4):381-392

64 Tufano A, Guida A, Di Minno MN, Prisco D, Cerbone AM, Di Minno G. Prevention of venous thromboembolism in medical patients with thrombocytopenia or with platelet dysfunction: a review of the literature. Semin Thromb Hemost 2011;37(3):267-274

65 Mariani G, Bernardi F. Factor VII deficiency. Semin Thromb Hemost 2009;35(4):400-406

66 Fava C, Montagnana M, Favaloro EJ, Guidi GC, Lippi G. Obstructive sleep apnea syndrome and cardiovascular diseases. Semin Thromb Hemost 2011;37(3):280-297 